\title{
Fusión de un tercer molar mandibular con un cuarto molar supernumerario
}

\section{Fusion of mandibular third molar with supernumerary fourth molar}

\section{López Carriches', I. Leco Berrocal2, R. Baca Pérez-Bryan³}

Resumen: La fusión dental es la unión de dos gérmenes dentales normalmente separados, mientras que la geminación se define como el intento de división de un único germen dental.

La fusión y geminación de molares es poco frecuente en la dentición permanente.

Describimos un caso clínico de un tercer molar inferior derecho fusionado a un cuarto molar supernumerario en un paciente varón de 36 años que ha presentado repetidos episodios de pericoronaritis. Tras el estudio radiológico se realiza la exodoncia del cordal semiincluido bajo anestesia local. Llevamos a cabo una revisión bibliográfica al respecto.

Palabras clave: Fusión dental; Geminación dental; Doble diente; Tercer molar; Cuarto molar.

Recibido: 06.11.2007

Aceptado: 29.04.2008

\begin{abstract}
Dental fusion is the union of two tooth buds that normally are separated, while gemination is defined as an attempt by a single tooth bud to divide.

The fusion and gemination of molars is uncommon in permanent teeth.

We report a clinical case of a right lower third molar fused to a supernumerary fourth molar in a 36-year-old male patient with repeated episodes of inflammation. After the radiologic study, the semi-impacted third molar was extracted under local anesthesia. The literature was reviewed.
\end{abstract}

Key words: Dental fusion; Dental germination; Double tooth; Third molar; Fouth molar.

\footnotetext{
1 Profesora Asociada de Cirugía.

2 Profesora Colaboradora de Cirugía.

3 Profesor Titular de Cirugía.

Facultad de Odontología. Universidad Complutense de Madrid. España
}

\section{Correspondencia:}

Dra. Carmen López Carriches

Departamento de Medicina y Cirugía Bucofacial

Facultad de Odontología. Universidad Complutense de Madrid. España 28040 Madrid. España

E-mail: carmen.lopez@uem.es 


\section{Introducción}

Las anomalías por unión de los dientes han recibido múltiples denominaciones: Fusión, geminación, doble diente, concrescencia, gemelación, etc. ${ }^{1}$

La definición se basa en cómo los dientes unidos se desarrollan, así la fusión se define como la unión de dos gérmenes dentales normalmente separados, mientras que la geminación es el intento de división de un único germen dental. El diagnóstico diferencial entre fusión y geminación es difícil cuando la unión envuelve un diente normal y un super-

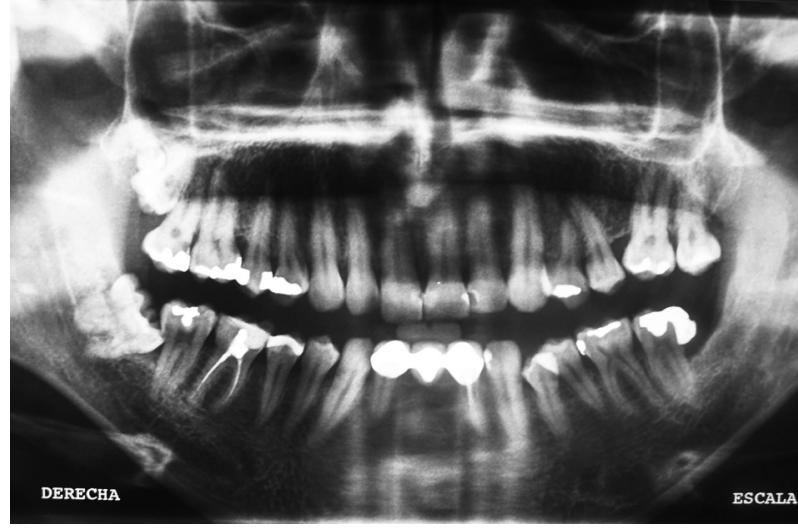

Figura 1. Ortopantomografía preoperatoria. Figure 1. Preoperative orthopantomography.
Introduction

Anomalies of the union of teeth have received many names: fusion, gemination, double teeth, concrescence, twinning, and others.

The definition is based on how the teeth that join together eventually develop. Consequently, fusion is defined as the union of two normally separated tooth germs, whereas gemination is the tentative division of a single dental germ. The differential diagnosis between dientes de la arcada disminuyen de número, puesto que se unen dos gérmenes de dos dientes distintos durante el desarrollo, por el contrario la geminación da como resultado un aparente aumento del número de dientes. Sin embargo, cuando el diente que se une es un supernumerario el número de dientes no disminuye a pesar de tratarse de una fusión. ${ }^{2,3}$ De forma genérica y para evitar controversias en la terminología muchos autores denominan estas anomalías como doble diente. ${ }^{4}$

La fusión y geminación de molares es poco frecuente en la dentición permanente. La prevalencia varía del 0,08\% al 0,5\%.4-8 Los incisivos centrales maxilares son los dientes que más frecuentemente presentan fusión o geminación $(3,55 \%)$ seguidos de los terceros molares mandibulares $(0,91 \%){ }^{4}$

La etiología de la fusión dental es desconocida. Se ha sugerido que la presión de los folículos dentales adyacentes que produce su contacto y fusión antes de la calcificación, la herencia o diferencias raciales pueden predisponer a la fusión. ${ }^{4,9}$ Se observa con más frecuencia en japoneses y en dentición temporal ${ }^{1}$ y no hay diferencia en cuanto al sexo. ${ }^{4}$

\section{Caso clínico}

Presentamos un caso clínico de un tercer molar fusionado a un cuarto molar supernumerario en un paciente varón de 36 años que acude al Departamento de Medicina y Cirugía Bucofacial por presentar episodios de dolor, inflamación y trismo de repetición causados por el tercer molar inferior derecho semierupcionado. En la exploración se observa un tercer molar de grandes dimensiones en posición mesioangular semierupcionado, responsable de los episodios de pericoronaritis. Realizamos una ortopantomografía en la que se observa el tercer molar unido a un supernumerario por la corona y la raíz (Fig. 1). Se da la circunstancia de que el paciente presenta otro molar supernumerario en el maxilar superior lado derecho (Fig. 2).

Tras realizar la historia clínica del paciente (sin antecedentes de interés), se explica al paciente el propósito y los riesgos de la intervención y firma el consentimiento informado. El paciente rechaza la posibilidad de realizar un escáner para conocer la relación del molar con el conducto del nervio dentario inferior. Se procede a la fusion and gemination is difficult when the union involves a normal tooth and a supernumerary tooth. In the case of fusion, the number of teeth in the arcade diminishes, since two germs of two different teeth join during development. In contrast, gemination results in an apparent increase in the number of teeth. However, when the other tooth in the union is a supernumerary tooth, the number of teeth does not decrease despite the existence of fusion. ${ }^{2,3}$ In order to avoid terminology controversies, many authors call these anomalies generically "double tooth". ${ }^{4}$

The fusion and gemination of molars are infrequent in permanent teeth. The prevalence ranges from $0.08 \%$ to $0.5 \% .^{4-8}$ The central maxillary incisors are the teeth most frequently involved in fusion or gemination (3.55\%), followed by the mandibular third molars (0.91\%). ${ }^{4}$

The etiology of dental fusion is not known. It has been suggested that the pressure of adjacent dental follicles produces their contact and fusion before calcification; heredity and racial differences may predispose to fusion. 4,9 Fusion is observed more frequently in the Japanese and in deciduous teeth. ${ }^{1}$ There is no difference between men and women in incidence. $^{4}$

\section{Clinical case}

We report a clinical case of a third molar fused to a supernumerary fourth molar in a 36-year-old man. He was seen in the Department of Buccofacial Medicine and Surgery for episodes of pain, inflammation, and repeated trismus caused by a partially erupted lower right third molar. In the examination, a third molar of large dimensions was observed in a partially erupted mesioangular position. This third molar was responsible for episodes of pericoronaritis. In orthopantomography, the third molar was joined to a supernumerary tooth by the crown and root (Fig. 1). The patient had another supernumerary molar in the right upper jaw (Fig. 2). 
extracción quirúrgica del tercer y cuarto molar, con anestesia local, siendo necesario hacer odontosección por el gran tamaño del molar fusionado (Figs. 3 y 4 ).

No hubo complicaciones ni intra ni postoperatorias.

El paciente acude a revisión a los tres meses, descartándose problemas periodontales y presencia de caries en el segundo molar.

\section{Discusión}

Revisando la literatura hay pocos estudios sobre la prevalencia de dientes dobles. ${ }^{4}$ La fusión dental es más frecuente en la dentición temporal, sobre todo en la región anterior. ${ }^{1}$ Esta fusión en dentición temporal suele dar lugar al retraso en la erupción del diente permanente o a su erupción ectópica por lo que se deben hacer controles radiográficos para valorar el desarrollo de los dientes definitivos y decidir su extracción si fuera necesario para evitar retrasos o problemas de erupción. En los dientes definitivos son los incisivos centrales maxilares los que más presentan esta anomalía seguidos del tercer molar mandibular. ${ }^{4}$ En la literatura también hay descritos casos de fusión de tercer y cuarto molar maxilar. ${ }^{10}$ De hecho en el caso que nos ocupa el paciente presenta también un molar supernumerario en el maxilar aunque no parece que estén unidos.

Los dientes fusionados no suelen dar ninguna sintomatología, se suelen diagnosticar cuando el paciente acude a consulta por presentar un diente "doble" en el sector anterior que le preocupa estéticamente por su tamaño o por producir apiñamiento o por presentar dolor por caries o pericoronaritis en el caso de molares. Aunque tienen una incidencia muy baja son anomalías dentales muy importantes pues su conocimiento facilitará el tratamiento de estos dientes ya sea endodóntico, reconociendo conductos fusionados, raíces muy incurvadas, etc.;9,11 ortodóncico ya que las raíces de estos dientes se resisten al movimiento; periodontal, que puede ser muy delicado cuan-

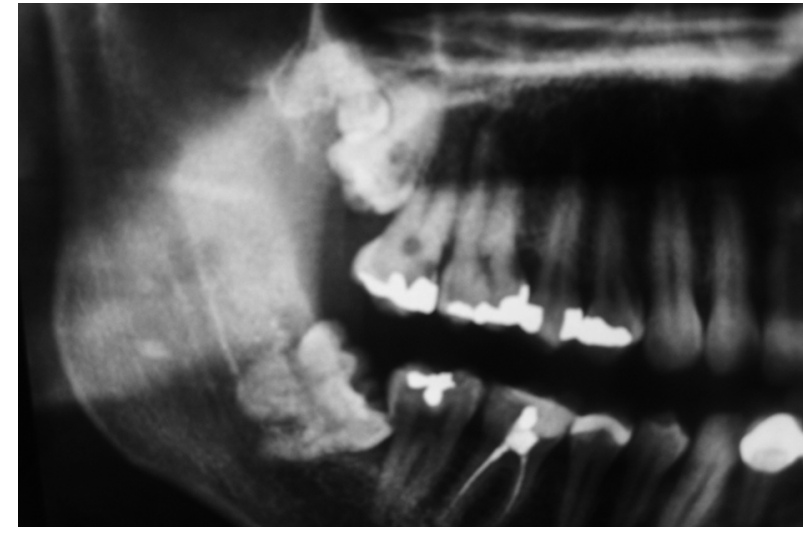

Figura 2. Detalle de ortopantomografía. Figure 2. Orthopantomography detail.

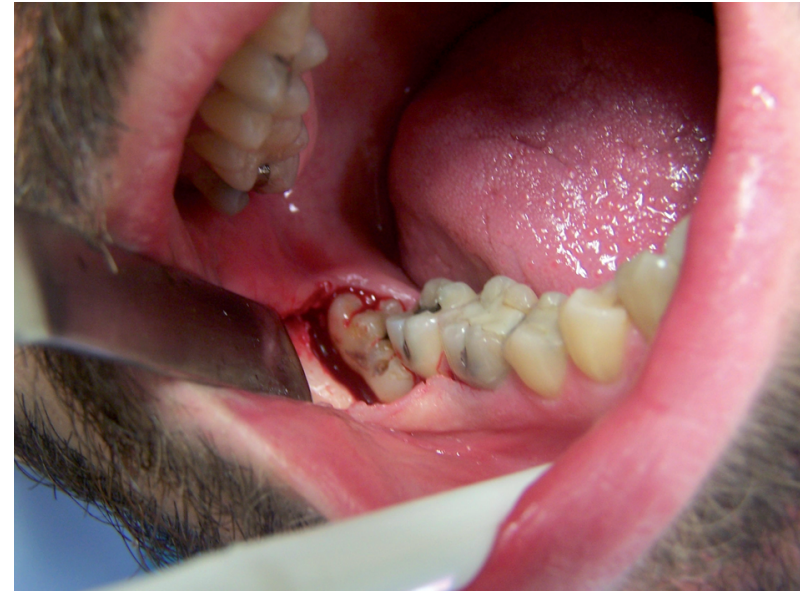

Figura 3. Tercer y cuarto molar fusionados y en posicición mesioangular.

Figure 3. Third and fourth molars fused in mesioangular position.

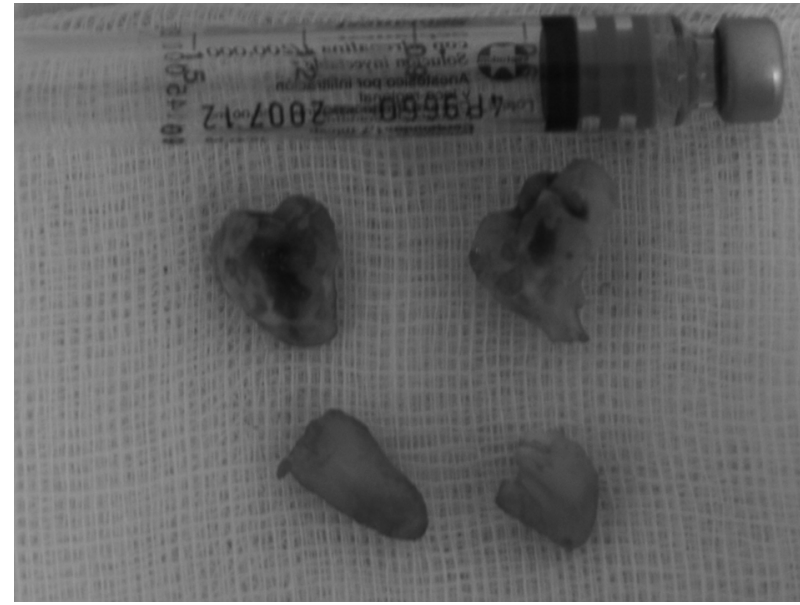

Figura 4. Molares exodonciados mediante odontoseción.

Figure 4. Molars removed by tooth section.
After the patient's clinical history was obtained (no history of interest), the purpose and risks of the intervention were explained to him and he signed the informed consent form. The patient rejected the possibility of undergoing a scan to determine the relation of the molar with the canal of the inferior dental nerve. The third and fourth molars were extracted surgically under local anesthesia. Tooth section was necessary due to the large size of the fused molar (Figs. 3 and 4).

There were no intraoperative or postoperative complications.

In the three month follow-up visit, periodontal problems were ruled out and a cavity was found in the second molar.

\section{Discussion}

In a review of the literature, there are few studies on the prevalence of double teeth. ${ }^{4}$ Dental fusion is more frequent in deciduous teeth, particularly in the anterior region. ${ }^{1}$ Fusion of deciduous teeth usually gives rise to delayed eruption or ectopic eruption of the permanent tooth. Radiographic follow-up should be conducted to evaluate the development of the permanent teeth and remove them if necessary to avoid eruption delays or problems. In the definitive teeth, the central maxillary incisors are the teeth that most frequently present this anomaly, followed by the mandibular third molar. ${ }^{4}$ Cases of fusion of the maxillary third and fourth molars also have been described in the literature. ${ }^{10}$ In fact, in the case in question the patient also presented a supernumerary molar in the maxilla, but it did not seem to be fused.

Fused teeth are generally asymptomatic. The condition usually is diagnosed when the patient visits the clinic for a double tooth in the anterior part of the mouth that causes cosmetic concern due to its size or because it produces crowding, pain 
do la unión se produce a nivel radicular; protésico pues al tallar se puede comprometer la vitalidad pulpar o quirúrgico, como en el caso que nos ocupa. En todos los casos es muy importante saber valorar la radiografía para no cometer errores de interpretación o pensar que pueda tratarse de artefactos. ${ }^{12}$

Por supuesto si el diente fusionado no produce sintomatología ni afecta a la estética no hará falta tratamiento alguno. ${ }^{13}$

En nuestro caso se procedió a la exodoncia del tercer y cuarto molar fusionados por los episodios repetidos de pericoronaritis y por el riesgo de problemas periodontales y caries en la cara distal del 47 debido a la impactación de alimentos. Coincidimos con el caso presentado por Henández-Guisado y colaboradores, ${ }^{13}$ de geminación de un 38 y un 39 que afirman que el hecho de que el cuarto molar tenga un volumen igual que el tercer molar y que el surco de unión vaya de la corona al ápice les induce a pensar que se unieron dos gérmenes independientes que no estaban separados por un septum óseo durante su desarrollo. El mismo tratamiento realiza Chen,, 3 en casos similares de unión de tercer y cuarto molar. En casos en que el tercer y cuarto molar quieran ser conservados porque el paciente tenga ausencia de primer $y / 0$ segundo molar y necesiten tratamiento endodóntico se pondrá especial atención en determinar el número de conductos y su forma. ${ }^{9}$

\section{Bibliografía}

1. Tomizawa M, Shimizu A, Hayashi S, Noda T. Bilateral maxillary fused primary incisors accompanied by succedaneous supernumerary teeth: report of a case. Int J Paediatr Dent 2002;12:223-7.

2. Chen HS, huang YL. Fusion of third and fourth mandibular molar? Oral Surg Oral Med Oral Pathol 1992;73:767.

3. Chen JR, Yang JF. Fusion of a third molar with an invaginated supernumerary molar. Oral Surg Oral Med Oral Pathol 1990;70:526-7.

4. Hamasha AA, Al-Khateeb T. Prevalence of fused and geminated teeth in Jordanian adults. Quintessence Int 2004;35:556-9.

5. Ruprecht A, Batniji S, El-Neweihi E. Double teeth: The incidence of fusion and germination. J Pedod 1985;9:332-3.

6. Salem G. Prevalence of selected dental anomalies in Saudí children from Gizan region. Community Dent Oral Epidemiol 1989;17:162-3.

7. Bruce C, Manning-Cox G, Stanback-Fryer C, Banks k, Gilliam M. A radiographic survey of dental anomalies in black pediatric patients. NDA J 1994; 45:6-13.

8. Backman B, Wahlin YB. Variations in number and morphology of permanent teeth in 7 years old Swedish children. Int J Paediatr Dent 2001;11:11-17.

9. Turell IL, Zmener O. Endodontic management of a mandibular third molar fused with a fourth molar. Int Endod J 1999;32:229-31.

10. Hou GL, Tsai CC. Fusion of maxillary third and supernumerary fourth molars. Case report. Austr Dent J 1989;34:219-22.

11. Turell IL, Zmener O. Endodontic therapy in a fused mandibular molar. J Endodon 1999;25:208-9.

12. Morris SO. Fusion of mandibular third and supernumerary fourth molars. Dent Update 1992;19:177-8.

13. Hernández Guisado JM, Torres-Lagares D, Infante-Cosío P, Gutiérrez-Pérez JL. Geminación dental: presentación de un caso. Med Oral 2002;7:231-6. due to cavities, or pericoronaritis in the case of molars. Although dental anomalies have a low incidence, they are important because awareness of their presence will facilitate treatment. Treatment may be endodontic, for fused canals, curved roots, etc. ${ }^{9,11}$ orthodontic, because the roots of these teeth are resistant to movement; periodontal, a procedure that may be delicate when the fusion affects the roots; prosthetic because resection may affect pulp vitality; or surgical, as in the case that occupies us here. In every case, it is important to know how to evaluate the radiograph to avoid committing interpretation errors or attributing the images to artifacts. $^{12}$

Of course, if the fused tooth does not produce symptoms or affect the patient's appearance, treatment will not be needed. ${ }^{13}$

In our case, the fused third and fourth molars were removed for repeated episodes of pericoronaritis and the risk of periodontal problems and tooth decay on the distal face of 47 due to impacted food. We agree with Henández-Guisado et al. ${ }^{13}$ regarding a case of gemination of 38 and 39 presented. Hernández-Guisado et al. claimed that the fact that the fourth molar has a volume equal to that of the third molar and that the fusion furrow extends from the crown to the apex suggests that two independent germs that were not separated by a bone septum during development fused together. Chen ${ }^{2,3}$ used the same treatment in similar cases of fusion of the third and fourth molars. If the aim is to conserve the third and fourth molars because the patient is missing the first and/or second molars and requires endodontic treatment, special attention will be paid to determining the number of canals and their form. ${ }^{9}$ 